\title{
Forestry and Canada's foreign aid program
}

\author{
by Ralph W. Roberts ${ }^{1}$ and John Roper ${ }^{2}$
}

Assistance in forestry has been provided to more than 100 developing countries across a span of more than a half-century. The delivery channels for this aid, through the Canadian International Development Agency, have remained relatively unchanged over the years. However, the level of funding as well as the nature and scope of the type of support provided continues to evolve. The emphasis in earlier years tended to focus on stand-alone projects aimed at forest industries development and economic expansion. More recently, despite budget cutbacks, priority has been given to improved governance in the sector through institutional strengthening and capacity building. Multi-sectoral approaches are favoured wherein trees and forests play a key role in sustaining the provision of a range of economic, environmental, social and cultural values. Examples of these types of projects in all parts of the world are described. The strong comparative advantage enjoyed by Canada in the sector positions CIDA to pursue with partners and other donors a number of new directions in addressing pressing forest management and conservation issues in the South.

Key words: development assistance, CIDA, IDRC, agroforestry, poverty alleviation, food security, deforestation, community forestry, national forest programs, international

L'aide accordée dans le domaine forestier s'est étendue à une centaine de pays en développement en plus d'un demi-siècle. Les voies d'acheminement de l'aide par l'entremise de l'Agence canadienne de développement international (ACDI) sont demeurées relativement inchangées au fil des ans. Toutefois, le niveau de financement ainsi que la nature et la portée de l'aide n'ont cessé d'évoluer. Antérieurement, l'accent était mis sur des projets ponctuels favorisant l'essor de l'industrie forestière et l'expansion économique. Plus récemment, malgré l'ampleur des réductions budgétaires, la priorité a été donnée à une gestion plus avisée des ressources du secteur, au moyen du renforcement institutionnel et de la création des capacités. Les approches multisectorielles, dans lesquelles les arbres et les forêts jouent un rôle primordial à l'appui d'une gamme étendue d'avantages économiques, environnementaux, sociaux et culturels, sont désormais privilégiées. Les auteurs donnent de nombreux exemples de ces types de projets répandus dans toutes les régions du monde. Le net avantage comparatif dont jouit le Canada dans le secteur place l'ACDI en bonne posture pour suivre, de concert avec ses partenaires et d'autres donateurs, des nouvelles orientations aptes à aborder les questions urgentes de la gestion et de la conservation de la forêt dans le Sud.

Mots-clés: aide au développement, ACDI, CRDI, agroforesterie, réduction de la pauvreté, sécurité alimentaire, déforestation, foresterie communautaire, programmes forestiers nationaux, international

Más de cien países en desarrollo han recibido asistencia para el sector forestal durante un período de más de medio siglo. Si bien los canales de entrega de esa ayuda, por medio de la Agencia Canadiense para el Desarrollo Internacional (CIDA/ACDI) no han cambiado mucho en lo sustancial, el nivel de financiamiento así como la naturaleza y alcance del tipo de apoyo proporcionado siguen evolucionando. Al comienzo se tendía a centrar el énfasis en proyectos autónomos destinados al desarrollo de industrias forestales y expansión económica. Ultimamente, y a pesar de los cortes presupuestarios, se asigna prioridad a una mejor gobernabilidad en el sector mediante fortalecimiento institucional y creación de capacidad. Se privilegian los enfoques pluri-sectorales en los cuales los árboles y bosques desempeñan una función esencial en sostener la entrega de una gama de valores económicos, ambientales y socio-culturales. Se describen ejemplos de este tipo de proyectos en todas partes del mundo. La fuerte ventaja comparativa que disfruta Canadá en el sector pone a la ACDI en buena posición para trabajar con socios y otros donantes en nuevas direcciones para abordar asuntos apremiantes de manejo y conservación forestal en el Sur.

Palabras claves: asistencia al desarrollo, CIDA/ACDI, IDRC/CIID, agro-silvicultura, alivio de la pobreza, seguridad alimentaria, deforestación, comunidad forestal, programas forestales nacionales, internacional

\section{Canada's Official Development Assistance Program}

Development assistance is a key element of Canada's foreign policy, a policy based on the interdependent and mutually reinforcing concepts of promoting sustainable prosperity and employment, enhancing global security, and projecting Canadian values and culture. These objectives are met through the collective efforts of many federal departments, principally the Canadian International Development Agency (CIDA),

${ }^{1}$ Director, Atlantic Canada Regional Office and Senior Advisory, Forestry and Conservation, Canadian International Development Agency, Moncton, New Brunswick E1C 1H1.

${ }^{2}$ International Forestry Consultant, Burnaby, British Columbia V5C 3V2.

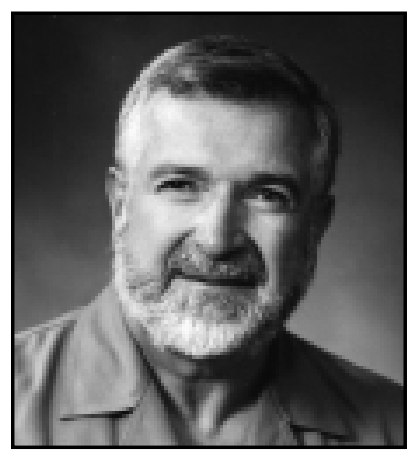

Ralph W. Roberts

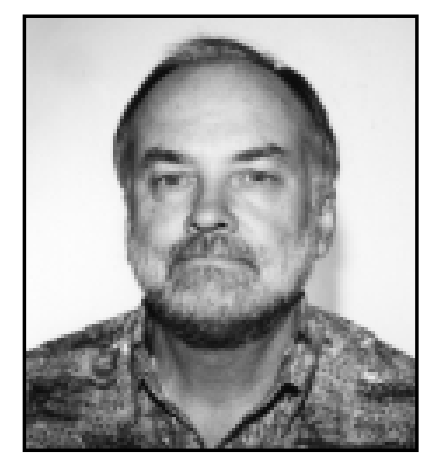

John Roper
Foreign Affairs and International Trade, and the International Development Research Centre (IDRC). 
CIDA is the branch of the Canadian government responsible for the delivery of Canada's official development assistance program (ODA) and assistance to Central and Eastern Europe. CIDA's goals are to contribute to sustainable development in countries in Africa and the Middle East, Asia, and Latin America and the Caribbean, as well as to support democratic development and economic liberalization in the countries in transition of Central and Eastern Europe. CIDA's programmes focus on strengthening economic, political, and socio-cultural capacities, reducing poverty, and addressing the key global challenges of a clean environment, human rights and gender equality, economic prosperity, good health and education, and human security.

CIDA administers development assistance through three delivery channels. The largest channel is the government-to-government programs that are administered through geographically oriented branches-Africa and the Middle East, Americas, Asia, and Central and Eastern Europe. The multilateral channel manages resources for food aid, international humanitarian assistance, the international financial institutions, and the United Nations agencies. Finally, the Canadian partnership channel responds to proposals from non-governmental organizations, educational institutions, the Canadian business community, and international organizations. In all cases, CIDA does not implement the assistance programs itself; rather, executing agencies are given the responsibility for actual implementation.

CIDA's current policy with respect to strengthening aid effectiveness is described in "Canada Making a Difference in the World," which can be found at www.acdi-cida.gc.ca/ aideffectiveness.

\section{Forestry's Role in Canada's ODA Program}

Forestry has been part of Canada's ODA program since the 1950s when assistance was provided in establishing forest industries in East Pakistan, now Bangladesh. Later assistance, from the early days of CIDA to the 1980s, tended to concentrate on assisting developing countries in building their forestry institutions through technical assistance and training projects. More recently, the emphasis has been on community forestry, restoration of degraded landscapes, and forest conservation, including becoming an integral part of Canada's response to meeting our international commitments to a number of multilateral agreements and conventions, to addressing rural poverty, and to revitalizing our contribution to agriculture development. Although not one of the specific objectives, it has been an important tool for achieving our development assistance goals. Forest and conservation programs provide the opportunity to address not only the critical natural resource and environmental challenges facing developing countries, but at the same time, the serious socio-economic problems of rural peoples.

CIDA forestry programming focuses on:

- expanding the economic and environmental benefits of trees on agricultural and fragile landscapes, particularly in support of agriculture production and water conservation;

- conserving the natural resource heritage of the world's poorest regions through the sustainable management of protected areas and lands adjacent to them;

- increasing the sustainable output of economic products from tree and forest resources through improved production systems for wood and non-wood forest products that benefit societies at large;
- improving human resource development and strengthening institutional capacities for the sustainable use of forests and related resources at the community, technical, and professional levels for all stakeholders in order to realize the full potential of a broad range of forest values; and

- developing stronger civil societies with a special emphasis on reforming forest governance, stewardship systems, and the adoption of equitable tenure system.

Forestry interventions are an integral part of the overall programming strategy for any given country or region. They can be effective, practical measures for addressing the challenges of sustainable development.

\section{CIDA's Forest and Conservation Program}

Forests in developing countries are important for their economic, environmental, and social values. Canadian co-operation assists in building capacities to realize the full potential of these forest values. For example, in Jamaica, Canada has been collaborating with the Jamaican Forestry Department to strengthen the management of the indigenous forest resource through a long-term, multidimensional project that involves institution building, education and training, resource assessment, watershed management, and a new national forestry programme. The management of watersheds is important for the production of potable water, irrigation for agriculture, and for human sanitation.

Meeting basic human needs is an important priority for Canada's ODA programme. This includes assisting people in achieving food security. In the late 1970s, Canada took the lead in the international community for the creation of the World Agroforestry Centre, formerly known as ICRAF, which undertakes research on the cultivation of trees on agricultural lands. In agroforestry, trees are planted on farmlands to improve soil fertility and food production, to provide animal fodder, and to produce wood products. Agroforestry offers considerable hope to resource-poor farmers as a way to increase agriculture production and achieve food security. In Southern Africa, Canada is supporting a very successful long-term agroforestry research program of ICRAF that is now disseminating its results to local farmers. On another front, assistance has been provided through CIDA's Partnership Branch to an international analogue forestry network that works with farmers in developing countries. Analogue forestry is an agroforestry system where farmers re-create the structure and ecological functions of the local natural forest ecosystem by planting tree and other plant species that provide them with a range of products for personal consumption or sale in the marketplace. Farmers benefit from the diversity of products that they harvest while at the same time restoring the natural environment and supporting key ecological processes.

Economically, forests worldwide can provide similar industrial forest products as are produced in Canada plus many locally important commodities like firewood and charcoal, food, traditional medicines, and a vast number of non-timber forest products. With Canada's support, the World Conservation Union (IUCN) is working with governmental and civil society organizations in Russia's Far East to enhance public involvement in forest management and conservation. The project's goal is to build local capacities in the use of participatory approaches to decision-making in forest conservation. It is a recognition of the widely accepted principle that suc- 
cessful conservation of public forest lands must involve a broad range of forest stakeholders in establishing goals, strategies, and priorities for action. The project strives to improve democratic governance in forest conservation, to establish a participatory framework for the management of Russia's forests, and to develop income-generation opportunities through the harvesting and marketing of non-timber forest products. One of the project's specific objectives is to develop income opportunities for women and indigenous communities from the sustainable use of non-timber forest products.

Also in Russia's Far East, the McGregor Model Forest Association is implementing the Natural Resource-Based Economic Development Project with local partners. It builds on the earlier Canadian experience in the Khabarovsk Krai gained during a model forest project. The project goal is to increase the Khabarovsk Krai's capacity to identify and respond to market opportunities within its natural resource sector. This is being done by increasing the skills of key business and government specialists and by creating new economic opportunities within the resource sector. To achieve its goal, the project works with forest stakeholders to improve the management, the quality of output, the range of goods and services, and the market exposure of local forest industries. It focuses on the creation of new enterprises and the improvement of existing ones. The project is providing technical assistance in the areas of business planning, financial management, human resource management, training, marketing, strategic planning, and strategic partnering between Canadian, Russian, and international organizations.

Forests in developing countries provide necessary environmental services including the conservation of the immensely rich tropical biodiversity, the sequestration and storage of atmospheric carbon, the conservation of fragile tropical soils, and the production and regulation of fresh water. Many of the services are of global importance. In Guyana, Canada is supporting the Iwokrama International Centre for Rain Forest Conservation and Development. Iwokrama is developing new approaches to managing 360000 hectares of tropical rain forests in South America through multidisciplinary research and application of new technologies for their conservation and sustainable use. In Central Africa, Cameroon boasts one of the largest tropical forests outside of the Amazon Basin. CIDA has been collaborating for many years with the Cameroon government and civil society in their efforts to introduce environmentally sustainable practices for the benefit of the people whose livelihoods depend on the forests.

Forests are also important from a social perspective as they form part of the cultural and spiritual heritage of many of the world's peoples. In Indonesia, the Kaltim Social Forestry Project works with local institutions in developing programmes and policies aimed at the equitable participation of rural people in the benefits of forest development. Some key aspects of the project are building local capacities in forest management and respecting the traditional forest rights of local stakeholders.

Through its Partnership Branch, CIDA supports the efforts in forestry of Canadian and international non-governmental organizations. Canadian and Bolivian NGOs are implementing the community-led Watershed Restoration in the Tarija Valley Project in Bolivia. The project promotes and supports community-based reforestation and soil conservation in order to protect the land from erosion, avoid flood damage, reduce deforesta- tion, and to provide food security for small rural farmers, through education and technical assistance.

\section{Canadian Aid Flows to Forests and Conservation}

Canada's development assistance funding going directly to forest and conservation activities has declined by more than $50 \%$ in the last decade. In 1989, aid flows through all delivery channels amounted to $\$ 98$ million in support of over 175 projects and programs. In contrast, support in 1999 was approximately $\$ 42$ million for about 100 initiatives. This decline has been the consequence of the Government of Canada's general reduction in ODA funding and a shift in programmatic priorities away from natural resource management to social development.

Recently, CIDA initiated a review of the role of agriculture in Canada's ODA program. With poverty alleviation and food security being important objectives and the majority of the world's poor living in rural areas, it is essential that greater support be given to agriculture in the future. However, agricultural development cannot occur in isolation from the wise stewardship of other natural resources. Forestry can play an important complementary role, not only for the introduction of environmentally sustainable agricultural practices like agroforestry but also in the strengthening of the role of wood products in the agricultural economies of developing countries. To a great extent, the future scope of forestry within our ODA program will be dependent on the eventual strategy adopted for this important sector.

\section{Canadian Capabilities and Comparative Advantage}

Compared to other countries and other sectors, the Canadian forest and conservation sector is well positioned to meet the challenges of international aid delivery in the 21 st century. It has strong capabilities in the private and public sectors to address the multi-sectoral issues facing the peoples and their environments in developing countries. As a forestry superpower, Canada is looked to by developing countries for leadership and assistance in finding sustainable solutions for the future of the global forests. The Canadian forest and conservation community is well experienced in international co-operation through the participation of our universities and technical schools, federal and provincial government departments, private sector, and numerous NGOs.

\section{Forestry at IDRC}

The Canadian Parliament created the International Development Research Centre (IDRC) in 1970, to stimulate and support research in developing countries. One of IDRC's three core themes-Environment and Natural Resource Managementis directly related to the sustainable management of forests. This theme focuses on enhancing forests' role in ensuring secure sources of food and water, improving human health and well-being by the sustainable management of ecosystems, and conservation of biodiversity. Priority is given to supporting research initiatives in production technologies, local resource management, and policy development. Research projects supported by IDRC build scientific competence and capacity of local researchers and the institutions they work for. Research in agroforestry and forest valuation have been successful areas of focus in recent years. 
IDRC has been supportive of the model forest concept as demonstrated by its hosting the International Model Forest Network Secretariat since 1995. IDRC also hosts the John G. Bene Fellowship in community forestry. The fellowship assists Canadian graduate students who are doing research on the role forests in the socio-economic and environmental well being of people in developing countries.

\section{Future Directions}

At the start of the 21 st century, there are promising new approaches - community forestry, agroforestry, carbon forestry, and the model forest concept - that are poised to make major contributions to forestry in the coming years. For the last two decades, community forestry and agroforestry have been growing in acceptance around the world. Our understanding of the scientific basis and the social organization necessary for these disciplines to succeed has reached the point where wider dissemination is now possible. In agroforestry, farmers choose to grow trees and shrubs with their crops or livestock because they provide additional important benefits the farmers need. Agroforestry can improve soil fertility, provide animal fodder, create a favourable micro-climate for crops and livestock, produce tree fruits, expand fuelwood supplies, and produce a variety of wood products for farmers' home use. Well-known examples of agroforestry include windbreaks, hedgerows, and mixed home gardens. Combining forestry and agriculture produces greater economic and environmental benefits for farmers than planting trees, growing crops, or raising animals alone. It is especially suited to small farmers who cannot afford the costly fertilizers and pesticides necessary for conventional farming.

Carbon forestry, the management of natural and planted forests for the sequestration and storage of atmospheric carbon, has the potential for enormous growth if workable international standards and monitoring systems can be agreed upon. The expansion of the International Model Forest Network offers the opportunity to advance scientifically based management through participatory approaches to forest stewardship. CIDA has been a strong supporter of the international model forest program from its inception. CIDA support has included bringing developing country representatives to Canada to familiarize them with the application of the process, providing guidance and support in the development of model forest proposals, funding model forest activities in the Chiloé Model Forest, supporting the participation of individuals to technical workshops sponsored by the IMFN, and supporting the activities of the IMFN Secretariat.

There is a need for better co-operation amongst donor agencies and developing countries to maximize the benefits from the scarce financial resources available. To make the most efficient use of these resources, it will be important that co-operation be strengthened among national governments, communities, non-governmental organizations, donor agencies and international institutions. The National Forestry Programs (NFP) that many countries have initiated are the most appropriate mechanism for achieving this. NFPs offer a multi-sectoral, multi-stakeholder approach to the planning and implementation of nationally identified priorities for investment in the forest sector. Donors also have an important role to play in catalyzing forest policy reform and private sector investment, perhaps by contributing to the establishment of an investment and development agency. The forestry sector was many years ahead of other disciplines when the Tropical Forestry Action Program was initiated in the mid-1980s with the specific objective of achieving this type of coordination.

Will development assistance in forestry and conservation be needed in the future? The answer is an unqualified Yes! The demand for forest products will continue to grow with the growth in the world economy and the world population. To meet these demands, investments will have to be made in both the sustainable supply of raw materials and in efficient manufacturing processes. The recognition of the environmental importance of forests will continue to grow, particularly in relation to the forests' contribution to soil conservation, regulation of stream and river flows, maintenance of local and global climates, and the conservation of biodiversity. For there to be any chance for sustainable development, resources must be invested in human resources at all levels. Policy reform, public participation and cross-sectoral linkages are vitally important to ensure that future development reflects the true concerns of society. To respond to these challenges, developing countries will continue to need assistance to efficiently manage their natural resources. Canada is well poised to provide that assistance. To do so, forestry and conservation must be part of Canada's commitment to international development. 